\title{
The Big Five Personality dengan Minat Beli Gamis pada Mahasiswi yang dimoderatori oleh Persepsi terhadap Kualitas Produk
}

\author{
Arga Prasetiya, Ratri Kurnia Ihsani, dan M. Luhung Pribadi \\ Pascasarjana Magister Profesi Psikologi Universitas Ahmad Dahlan \\ argajanuari21@gmail.com,ratri_kurnia_ihsani@yahoo.com, luhung76@gmail.com
}

\begin{abstract}
This study aims to find out the relationship between the big five personality with the buying interest of the robe, which moderated by the perception of the product quality at Ahmad Dahlan University Yogyakarta students. A total of 65 students from Ahmad Dahlan University in Yogyakarta from various faculties and any major. The data collection of the research sample was carried out by a cluster sampling technique. This research using the big five personality inventory (BFI), the scale of perception of product quality, and the scale of buying interest. Research data analysis was performed by analysis using path analysis techniques. The results showed a negative relationship between the big five personality and buying interest which was moderated by the perception of the product at Ahmad Dahlan University Yogyakarta students. The path of analysis coefficient shows the total impact of $\mathrm{p}=-0.10$. The total impact is smaller than the direct impact of the big five personality with buying interest which shows the path analysis coefficient of $p=0.07$. These results indicate that the perception of product quality as a moderator variable has a negative impact on the relationship between the big five personality and buying interest. Based on the results of the study, the hypothesis proposed in the study was rejected.
\end{abstract}

Keyword : big five personality, perception of product quality, buying interest

\begin{abstract}
Abstrak
Penelitian ini bertujuan untuk mengetahui hubungan antara big five personality dengan minat beli gamis yang dimoderatori oleh persepsi terhadap kualitas produk pada mahasiswi Universitas Ahmad Dahlan Yogyakarta. Subjek penelitian ini adalah mahasiswi Universitas Ahmad Dahlan Yogyakarta sejumlah 65 orang yang berasal dari berbagai fakultas dan program studi. Pengambilan data sampel penelitian dilakukan dengan teknik cluster sampling. Metode penelitian yang digunakan adalah menggunakan skala big five personality inventory (BFI), skala persepsi terhadap kualitas produk, dan skala minat beli. Analisis data penelitan dilakukan dengan analisis menggunakan teknik path analysis. Hasil penelitian menunjukkan hubungan negatif antara big five personality dengan minat beli yang dimoderatori oleh persepsi terhadap produk pada mahasiswi Universitas Ahmad Dahlan Yogyakarta. Koefisien analisis jalur menunjukkan total dampak sebesar $\mathrm{p}=-0,10$. Dampak total tersebut lebih kecil dibandingkan dampak langsung big five personality dengan minat beli yang menunjukkan koefisien analisis jalur sebesar $p=0,07$. Hasil tersebut menunjukkan bahwa persepsi terhadap kualitas produk sebagai variabel moderator memberikan dampak negatif kepada hubungan antara big five personality dengan minat beli. Berdasarkan hasil penelitian tersebut makahipotesis yang diajukan dalam penelitian ditolak.
\end{abstract}

Kata Kunci: big five personality, persepsi terhadap kualitas produk, minat beli

\section{Pendahuluan}

Dewasa ini masyarakat luas mengenal beragam produk pakaian yang bergerak dinamis dalam trend dunia mode. Salah satu trend mode yang sedang ramai menjadi perbincangan dan minat masyarakat dalam beberapa tahun belakangan ini ialah trend mode busana muslim. Trend mode busana muslim tersebut meliputi beberapa produk diantaranya gamis, hijab dan dress muslimah (Tempo.co, 2013). Informasi trend mode yang popular dalam berbagai media menjadikan masyarakat memberikan atensi kepada trend mode gamis dan hijab. Atensi yang diberikan oleh masyarakat luas terhadap trend mode dan produk busana muslim tersebut begitu besar. Sikap masyarakat tersebut berdampak pada munculnya fenomena meningkatnya minat beli pada masayarakat terkait produk busana muslim khususnya gamis. 
Berdasarkan uraian fenomena di atas, minat beli masyarakat meningkat seiring dengan atensi yang diberikan masyarakat terhadap trend mode pakaian gamis. Mowen (1995) menyatakan bahwa minat beli merupakan kecenderungan konsumen untuk membeli suatu merek atau mengambil tindakan yang berhubungan dengan pembelian dan diukur dengan tingkat kemungkinan konsumen melakukan pembelian. Selanjutnya, minat beli seseorang terkait dengan karakteristik yang dimiliki seseorang.

Amstrong dan Kotler (2003) menyebutkan beberapa faktor yang dapat mempengaruhi keputusan pembelian konsumen yaitu faktor budaya, faktor sosial, pribadi dan psikologis. Pada faktor pribadi Kotler menjelaskan keputusan pembelian dapat dipengaruhi oleh karakteristik pribadi diantaranya usia dan tahap siklus hidup, pekerjaan, keadaan ekonomi, gaya hidup, serta kepribadian dan konsepdiri pembeli. Hal ini dapat dilihat bahwa kepribadian merupakan salah satu faktor yang dapat mempengaruhi keputusan pembelian konsumen.

Berdasarkan penelitian Wang dan Yang tentang Passion for Online Shopping: The Influence of Personality and Compulsive Buying menjelaskan tiga ciri-iri kepribadian dari big-five personality (openness to experience, agreeableness and conscientiousness) dapat memicu individu untuk memperkuat keinginan akan kegiatan belanja online. Penjelasan tersebut dapat menerangkan bahwa meningkatnya minat beli masyarakat khususnya mahasiswi terhadap produk gamis berhubungan dengan komponen kepribadian. Tinjauan minat beli terhadap komponen kepribadian dalam penelitian ini ditinjau menggunakan paradigma kepribadian trait big-five personality.

Minat beli seseorang terhadap suatu produk terkait dengan aktivitas pertimbangan terkait merek, preferensi dan nilai produk. Selanjutnya, untuk memberikan suatu penilaian terhadap suatu produk dilakukan melalui proses persepsi. Persepsi menurut Gibson, dkk (2012) adalah proses yang dilakukan seseorang dalam memberikan makna terhadap lingkungannya. Proses pemaknaan tersebut melibatkan pengorganisasian, dan interpretasi berbagai stimulus lingkungan, untuk kemudian menjadi pengalaman psikologis (psychological experience). Sehubungan dengan fenomena tersebut, persepsi yang diberikan seseorang menghasilkan suatu penilaian terkait produk tersebut sehingga mempengaruhi minat beli seseorang terhadap suatu produk.

Fenomena minat beli terhadap produk gamis pada masyarakat khususnya mahasiswi berhubungan dengan pertimbangan terhadap nilai suatu produk yang berasal dari persepsi. Penilaian yang muncul terhadap suatu produk melalui proses persepsi akan memberikan informasi berupa psychological experience kepada seseorang dalam melakukan pertimbangan untuk membeli suatu produk. Minat beli masyarakat terhubung dengan karakteristik kepribadian dalam memunculkan kecenderungan perilaku membeli produk. Karakteristik kepribadian merupakan bagian diri seseorang yang mengarahkan sikap dan perilaku terkait pembelian suatu produk.

Berdasarkan survei yang dilakukan, enam dari sepuluh mahasisiwi yang menggunakan hijab memilih busana gamis yang sedang menjadi trend saat ini. Survei tersebut menunjukkan gamis menjadi produk yang sering dibeli dibandingkan model baju lainnya. Berdasarkan uraian terkait fenomena minat beli masyarakat terhadap busana gamis di atas, peneliti tertarik untuk meneliti tinjauan big five personality terhadap minat beli busana gamis pada mahasiswi yang dimoderatori oleh persepsi terhadap produk. Penelitian ini bertujuan untuk mengetahui hubungan antara karakteristik kepribadian seseorang ditinjau dari paradigma big five personality terhadap minat beli pakaian gamis pada mahasiswi yang dimoderatori oleh persepsi terhadap produk.

Minat Beli-Minat beli merupakan kecenderungan konsumen untuk membeli suatu merek atau mengambil tindakan yang berhubungan dengan pembelian yang diukur dengan tingkat kemungkinan konsumen melakukan pembelian (Assael,2008). Selanjutnya, minat beli sebagai perilaku transaksi konsumen cenderung muncul setelah mengevaluasi produk dan mengukur kemungkinan pembelian yang dilakukan konsumen kepada suatu produk (Schiffman \& Kanuk, 2010). Berdasarkan penjelasan tersebut, minat beli konsumen didefinisikan sebagai kecenderungan konsumen untuk membeli suatu merek atau mengambil tindakan yang berhubungan dengan pembelian yang diukur dengan tingkat konsumen melakukan pembelian.

Minat beli merupakan kecenderungan dari masing-masing konsumen untuk membeli suatu merek atau mengambil tindakan yang berhubungan dengan perilaku pembelian yang diukur dengan tingkat kemungkinan konsumen melakukan pembelian terhadap produk (Lucas \& Britt, 2012). Selain itu, minat beli merupakan suatu pernyataan mental dari konsumen yang merefleksikan rencana pembelian produk dengan merek tertentu. Berdasarkan penjelasan tersebut dapat disimpulkan bahwa minat beli 
merupakan sesuatu yang berhubungan dengan rencana-rencana konsumen untuk membeli produk tertentu serta berapa banyak unit produk yang dibutuhkan konsumen pada periode tertentu.

Lucas dan Britt (2012) mengatakan bahwa aspek-aspek yang terdapat dalam minat beli antara lain: (1) Perhatian, adanya perhatian yang besar dari konsumen terhadap suatu produk (barang atau jasa). (2) Ketertarikan, setelah adanya perhatian maka akan timbul rasa tertarik. (3) Keinginan, berlanjut pada perasaan untuk memiliki suatu produk tersebut. (4) Keyakinan, timbul keyakinan pada diri individu terhadap produk tersebut sehingga menimbulkan keputusan (proses akhir) untuk memperolehnya dengan tindakan yang disebut membeli.

Kotler \& Keller (2012) mengemukakan beberapa faktor yang membentuk minat beli konsumen yaitu: (1) Sikap orang lain, yaitu sejauh mana sikap orang lain mengurangi alternatif yang disukai seseorang akan bergantung pada dua hal yaitu, intensitas sifat negatif orang lain terhadap alternatif yang disukai konsumen dan motivasi konsumen untuk menuruti keinginan orang lain. (2) Faktor situasi yang tidak terantisipasi, faktor ini nantinya akan dapat mengubah pendirian konsumen dalam melakukan pembelian. Hal tersebut tergantung dari pemikiran konsumen sendiri, apakah dia percaya diri dalam memutuskan membeli suatu barang atau tidak.

\section{The Big Five Personality}

Kepribadian atau personality menurut Allport merupakan organisasi dinamis di dalam individu yang terdiri dari system-sistem psikofisis yang menentukan tingkah laku dan pikiran seseorang secara karakteristik (Chaplin, 2014). Selanjutnya, kepribadian adalah karakteristik (pola trait) yang khas dari seseorang yang menyebabkan munculnya perasaan, fikiran, dan tingkah laku secara konsisten dalam merespon situasi (Alwisol, 2012). Pola trait yang khas dari seseorang akan membedakan satu orang dengan yang lainnya dalam memunculkan perilaku. Salah satu model model untuk melihat gambaran sifat kepribadian manusia adalah dimensi kepribadian The Big Five Personality yang dikembangkan oleh McCrae dan Costa.

The Big Five Personality merupakan tinjauan kepribadian manusia berdasarkan analisis faktor yang dilakukan terhadap trait kepribadian (Feist \& Feist, 2008). Tinjauan kepribadian Big Five merupakan pengembangan lanjut dari dimensi-dimensi personality Eysenck. Selanjutnya, McCrae dan Costa mengelompokkan model kepribadian tersebut menjadi lima kelompok dimensi kepribadian meliputi openness, conscientiousness, extraversion, agreeableness dan neuroticism. Berdasarkan penjelasan tersebut dapat disimpulkan bahwa big five personality merupakan pola karakteristik khas dalam lima dimensi kepribadian yang menggambarkan pola karakteristik khas seseorang.

McCrae dan Costa (Feist \& Feist, 2008) menjelaskan The Big Five Personality terdiri dari lima dimensi (trait) yang mewakili sifat kepribadian individu. Kelima dimensi The Big Five Personality yang dikemukakan oleh McCrae \& Costa adalah sebagai berikut:

Extraversion menunjukkan ketertarikan individu terhadap hubungan interpersonal. Ketertarikan ini membuat individu cenderung mudah bergaul dan mampu menunjukkan kasih sayang terhadap individu lain. Sifat negatif dari individu yang mempunyai skor rendah pada tipe ini adalah cenderung lebih pendiam, serius dan sering menyendiri.

Agreeableness menunjukkan individu yang mempunyai kepercayaan terhadap orang lain. Kepercayaan yang dimiliki membuat individu dengan tipe agreeableness cenderung kooperatif dan tunduk pada orang lain. Tunduk dalam hal ini mengartikan bahwa individu mampu untuk patuh kepada orang yang telah dipercaya. Sifat lain yang dimiliki dapat dilihat dari cara berpikir, berperasaan, dan berperilaku. Tipe ini termasuk orang yang ramah dan bersahabat. Sifat negatif yang ditunjukkan oleh individu yang mempunyai skor rendah pada tipe agreeableness adalah adanya perasaan yang penuh kecurigaan serta suka bermusuhan.

Conscientiousness menunjukkan individu yang mempunyai disiplin diri. Hal tersebut ditunjukkan dengan kemampuan individu untuk mengatur waktunya dengan baik. Disiplin diri yang dimiliki didukung dengan ambisi yang kuat serta keinginan untuk bekerja. Ambisi serta keinginan tersebut membuat individu cenderung berorientasi pada prestasi. Sebaliknya, sifat negatif yang muncul pada individu dengan skor rendah adalah kurangnya motivasi yang dimiliki sehingga mudah menyerah dan cenderung tidak mempunyai tujuan. Hal tersebut membuat individu cenderung malas, tidak teratur serta kurang menghargai waktu sehingga lebih sering terlambat.

Neuroticism menunjukkan kestabilan dan ketidakstabilan emosi individu. Menilai kecenderungan individu dalam mengelola emosinya. Individu dengan skor tinggi pada tipe ini cenderung lebih cemas 
serta emosional. Sebaliknya, individu dengan skor rendah cenderung lebih tenang serta mempunyai kemantapan emosional yang positif.

Openness to experience menilai individu dalam menggali sesuatu yang baru. Hal ini membuat individu cenderung penasaran akan hal baru dan mempunyai kebebasan dalam berimajinasi. Sebaliknya, sifat yang dimiliki oleh individu dengan skor rendah pada tipe openness to experience cenderung realistis dan konservatif.

Berdasarkan penjelasan di atas dapat disimpulkan terdapat lima dimensi dalam The Big Five Personality meliputi extraversion $(E)$, agreeableness $(A)$, conscientiousness $(C)$, neuroticism $(N)$, dan openess to experience $(O)$.

Menurut Allport (Feist \& Feist, 2006) terdapat faktor-faktor yang mempengaruhi kepribadian yaitu: faktor genetik meliputi faktor yang diwariskan secara genetik kepada setiap individu sehingga menciptakan individual differencies dan faktor sosial yaitu adanya perbedaan lingkungan memberikan pengaruh kepada seseorang meliputi lingkungan, budaya, bahasa dan interaksi di lingkungan sosial.

Persepsi terhadap Kualitas Produk

Menurut Kotler (2003) persepsi juga mengarah pada pengambilan keputusan dan keputusan untuk bertindak atau tidak bertindak tergantung pada bagaimana mengembangkan motivasi. Pengertian produk dijelaskan oleh Kotler (2009) merupakan segala sesuatu yang dapat ditawarkan kepasar untuk mendapatkan perhatian, dibeli, digunakan, atau dikonsumsi yang dapat memuaskan keinginan atau kebutuhan. Kualitas produk adalah kemampuan suatu produk untuk melaksanakan fungsinya meliputi daya tahan keandalan, ketepatan kemudahan operasi dan perbaikan, serta atribut bernilai lainnya (Kotler \& Amstrong, 2008).

Persepsi yang dilakukan konsumen merupakan proses yang melibatkan penginderaan manusia dan komponen psikologis dalam melakukan pemberian makna atau penilaian terhadap suatu objek berupa produk. Menurut Durianto, dkk (2001) persepsi konsumen terhadap kualitas keseluruhan dari suatu produk atau jasa menentukan nilai dari produk atau jasa tersebut dan berpengaruh secara langsung kepada keputusan pembelian konsumen dan loyalitas mereka terhadap merek. Berdasarkan penjelasan tersebut dapat disimpulkan bahwa persepsi kualitas produk adalah proses penilaian yang dilakukan konsumen terhadap kualitas suatu produk untuk kemudian berpengaruh pada keputusan konsumen dalam pembelian.

Kotler dan Keller (2007) mengemukakan enam dimensi persepsi terkait kualitas produk yaitu: (1) Mutu kinerja (performance), dimensi yang paling basic terkait dengan fungsi utama dari suatu produk. (2) Keandalan (reliability), adalah ukuran kemungkinan suatu produk tidak akan rusak atau gagal dalam suatu periode tertentu. (3) Keistimewaan (feature), sebagian besar produk dapat ditawarkan dengan berbagai keistimewaan, yakni karakteristik yang melengkapi fungsi dasar produk. (4) Daya tahan (durability), menunjukkan suatu pengukuran terhadap siklus produk, yaitu ukuran usia yang diharapkan atas beroperasinya produk dalam kondisi normal dan atau berat baik secara teknis maupun waktu. (5) Mutu kesesuaian (conformance quality) menunjukkan seberapa jauh suatu produk dapat menyamai standar atau spesifikasi tertentu. (6) Gaya (style)yaitu menawarkan aspek emosional dalam mempengaruhi kepuasan pelanggan.

Berdasarkan tinjauan teoritik dan penjelasan terkait permasalahan di atas, maka hipotesis yang diajukan dalam penelitian ini adalah: ada hubungan big five personality dengan minat beli gamis yang dimoderatori persepsi terhadap kualitas produk. Persepsi terhadap kualitas produk sebagai variable moderator akan meningkatkanatau menguatkan hubungan big five personality sehingga berdampak pada meningkatnya minat beli.

\section{Metode Penelitian}

Penelitian yang dilakukan merupakan penelitian kuantitaif dengan satu variabel bebas (independent variable), satu variabel moderator (moderating variable) dan satu variabel tergantung (dependent variable). Variabel tergantung pada penelitian ini adalah minat beli produk dengan Big Five personality sebagai variabel bebas dan persepsi terhadap kualitas produk sebagai variabel moderator.

Sampel dalam penelitian ini adalah sejumlah 65 mahasiswi Universitas Ahmad Dahlan Yogyakarta. Kriteria subjek dalam penelitian ini merupakan mahasiswi yang sedang menempuh sarjana strata satu (S1) dan menempuh program pasca sarjana (S2) dengan rentang usia 20 hingga 25 tahun. Sampel penelitian diambil dengan menggunakan teknik cluster random sampling. Sampel dari populasi 
penelitian yang akan digunakan pada penelitian ini berfokus pada mahasiswi UAD kampus 1 yang terdiri dari fakultas psikologi, fakultas ekonomi, fakultas tarbiyah dan program pasca sarjana. Subjek dalam penelitian ini dipilih secara acak atau random.

Minat beli diungkap dengan menggunakan skala minat beli yang disusun oleh peneliti dengan mengacu pada aspek minat beli Lucas dan Britt (2012). Skala minat beli produk terdiri dari 24 item yang mengungkap aspek perhatian, ketertarikan, keinginan dan keyakinan.

Big Five Personality dalam penelitian ini diungkap dengan cara mengadopsi Big Five Inventory (BFI) dari Goldberg (dalam John \& Srivastava, 1999) yang sebelumnya telah diadopsi oleh Suyono, Aulia dan Tentama (2015). Skala Big Five Inventory terdiri dari 44 item yang mengukur dimensi kepribadian Big Five personality.

Persepsi kualitas produk diungkap dengan menggunakan skala persepsi kualitas produk dengan mengacu pada Kotler dan Keller (2007) yang disusun oleh peneliti. Jumlah item skala persepsi kualitas produk terdiri dari 24 item. Skala persepsi kualitas produk mengungkap dimensi mutu produk, keandalan (reliability), keistimewaan, daya tahan produk, kesesuaian produk (conformance quality) dan gaya (style).

Subjek pada penelitian ini diperoleh dengan menanyakan pertanyaan terkait kesediaan menjadi bagian dari subjek penelitian. Adapun subjek yang bersedia kemudian mengisi booklet yang berisi formulir identitas dan skala penelitian. Subjek penelitian kemudian dipersilahkan untuk mengisi booklet skala di tempat ataupun dibawa hingga waktu pengambilan skala sesuai kesepakatan dengan peneliti. Penelitian ini tidak memberikan reward apapun kepada subjek penelitian.

Analisis data dilakukan dengan menggunakan analisis dengan menggunakan program LISREL version 8.70. Teknik analisis jalur atau path analysis pada penelitian ini digunakan untuk menunjukkan adanya hubungan dan dampak yang diberikan baik secara langsung maupun tidak langsung antara variabel bebas terhadap variabel tergantung dengan adanya variabel moderator.

\section{Hasil dan Pembahasan}

Hasil Penelitian

Berdasarkan data penelitian yang diperoleh, uji asumsi menunjukkan bahwa data penelitian yang diperoleh telah memenuhi persyaratan uji asumsi yaitu data penelitian berdistribusi normal. Selanjutnya analisis data terkait dengan analisis goodness of fit penelitian disajikan melalui tabel berikut:

Tabel 1. Goodness of fit penelitian

\begin{tabular}{cccc}
\hline Goodness of fit index & Cutt off value & Data & Keterangan \\
\hline Kai Kuadrat empiris & $<2 \mathrm{db}$ & 0 & Fit \\
Signifikasi (p) & $\geq 0,05$ & 1 & Fit \\
RMSEA & $\leq 0,08$ & 0,0 & Fit \\
Chi square & $\geq 0,05$ & 1 & Fit \\
GFI & $\geq 0,90$ & 1 & Fit
\end{tabular}

Hasil uji goodeness of fit penelitian yang dilakukan menunjukkan bahwa model penelitian yang dilakukan telah memenuhi kriteria yang dianggap fit dan layak untuk diintegrasikan. Gambaran terkait dengan model yang menunjukkan hubungan maupun jalur antar variabel penelitian dapat ditunjukkan pada gambar struktur model berikut:

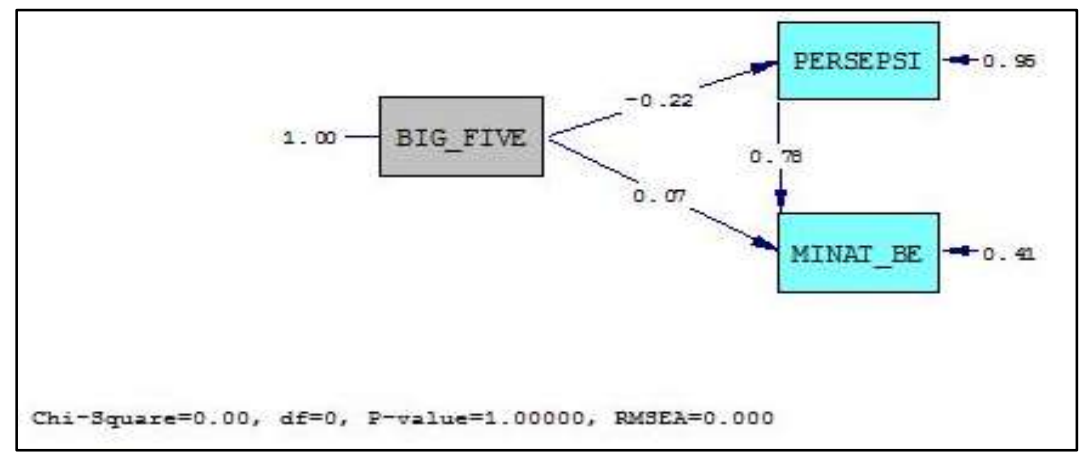

Gambar 1. Struktur dan Koefisiensi Jalur 
Berdasarkan gambaran terkait dengan struktur penelitian di atas, besaran pengaruh atau efek pada variabel-variabel penelitian dapat dilihat pada tabel berikut:

Tabel 2. besaran dan efek analisis jalur

\begin{tabular}{lcccc}
\hline \multicolumn{1}{c}{ Variabel } & Korelasi & $\begin{array}{c}\text { Dampak Langsung } \\
\text { (DE) }\end{array}$ & $\begin{array}{c}\text { Dampak Tidak } \\
\text { Langsung (IE) }\end{array}$ & $\begin{array}{c}\text { Total Dampak } \\
\text { (TE) }\end{array}$ \\
\hline BIG- PP & $-0,22$ & -0.22 & -- & -0.22 \\
BIG- MB & $-0,10$ & 0.07 & -0.17 & -0.10 \\
PP- MB & 0,77 & 0.78 & -- & 0.78 \\
\hline
\end{tabular}

Peneliti melakukan analisis korelasi menggunakan LISEREL. Hasil menunjukkan tidak adanya hubungan yang signifikan antara variabel Big-five dan minat beli dengan besar korelasi -0.10 . Dampak yang diberikan kecil yaitu sebesar 0,07 . Selain itu hasil analisis menjelaskan hubungan yang tidak signifikan antara Big-five dan persepsi kualitas produk dengan besar korelasi -0,22. Persepsi kualitas produk tidak memberikan dampak langsung dengan besaran dampak -0,22. Namun pada hubungan persepsi kualitas produk dan minat beli memiliki korelasi yang signifikan sebesar 0,77 dengan besaran dampak 0,78. Secara umum hasil ini menunjukkan bahwa hubungan big-five dan minat beli yang dimoderatori persepsi kualitas produk tidak signifikan. Namun big-five memiliki hubungan langsung terhadap minat beli. Big-five dapat mepengaruhi minat beli jika tidak dimoderatori oleh persepsi kualitas produk.

Pembahasan

Berdasarkan pemaparan data statistik diatas, maka hasil dalam penelitian ini adalah hubungan Big Five Personality dengan minat beli seseorang yang dimoderatori oleh persepsi terhadap kualitas produk menunjukkan total dampak sebesar-0,10. Hasil tersebut menunjukkan bahwa hipotesis penelitian terkait tinjauan hubungan Big Five Personality dengan minat beli yang dimoderatori oleh persepsi terhadap kualitas produk diterima dengan pengaruh negatif.

Berdasarkan hasil penelitian dan telaah penelitian-penelitian yang telah dilakukan sebelumnya mengasumsikan bahwa penelitian ini masih memiliki banyak terdapat kekurangan. Adapun beberapa keterbatasan dan kekurangan pada penelitian ini adalah adanya faktor social desirability pada alat ukur persepsi yang menyebabkan subjek penelitian mengisi pernyataan tidak sesuai dengan keadaan dirinya namun menyesuaikan norma yang ada dalam lingkungan sekitarnya. Selanjutnya, teknik sampling yang digunakan belum sepenuhnya di eksplorasi, sehingga sampel yang terpilih tidak sesuai dengan maksud penelitian. Kekurangan lainnya pada penelitian ini salah satu data variabel penelitian, yaitu pada big five personality yang tidak memenuhi uji asumsi linearitas, sehingga hasil penelitian hanya dapat di generalisir kepada subjek yang digunakan sebagai sumber data penelitian.

Kepribadian berdasarkan teori memiliki hubungan dengan minat beli karena merupakan salah satu faktor yang mempengaruhi. Namun berdasarkan penelitian ini, kepribadian yang di moderatori persepsi menunjukkan dampak yang negatif. Hal itu terkait dengan persepsi seseorang yang menghasilkan penilaian seseorang terhadap produk. Penilaian yang negatif terhadap produk akan berdampak pada menurunnya minat beli. Berdasarkan penjelasan tersebut maka pernilaian terhadap produk tidak sejalan dengan konsep kepribadian. Hal tersebut disebabkan kepribadian bersifat menetap sedangkan persepsi dapat dipengaruhi eksternal maupun objek dari luar seseorang. Hal ini telah dijelaskan oleh Feist \& Feist (2008), The Big Five Personality merupakan tinjauan kepribadian manusia berdasarkan analisis faktor yang dilakukan terhadap trait kepribadian. McCrae dan Costa mengelompokkan model kepribadian tersebut menjadi lima kelompok dimensi kepribadian meliputi openness, conscientiousness, extraversion, agreeableness dan neuroticism. Minat beli merupakan kecenderungan dari masing-masing konsumen untuk membeli suatu merek atau mengambil tindakan yang berhubungan dengan perilaku pembelian yang diukur dengan tingkat kemungkinan konsumen melakukan pembelian terhadap produk (Lucas \& Britt, 2012). Menurut Kotler (2007) persepsi juga mengarah pada pengambilan keputusan dan keputusan untuk bertindak atau tidak bertindak tergantung pada bagaimana mengembangkan motivasi.

\section{Kesimpulan}

Berdasarkan penelitian yang telah dilakukan dapat disimpulkan bahwa terdapat hubungan yang menghasilkan dampak negatif pada big five personality dengan minat beli yang dimoderatori oleh 
persepsi terhadap kualitas produk. Persepsi yang merupakan variabel moderator memberikan dampak negatif yang ditunjukkan oleh koefisien total dampak (p) pada analisis jalur atau path analysis. Hasil dari total dampak kepada minat beli sebagai variabel tergantung menunjukkan nilai $\mathrm{p}=-0,10$, sehingga nilai hubungan memberikan dampak negatif. Adapun big five personality yang memberikan dampak langsung terhadap minat beli menunjukkan nilai $\mathrm{p}$ sebesar 0,07 yang ditunjukkan pada hasil analisis jalur.

Penelitian yang dilakukan menunjukkan bahwa kepribadian seseorang memiliki hubungan terhadap meningkatnya minat beli seseorang namun memberikan dampak negatif kepada minat beli dengan adanya persepsi seseorang terkait kualitas produk sebagai moderator. Adapun hasil penelitian tersebut menunjukkan bahwa hipotesis yang diajukan dalam penelitian ini ditolak. Hal tersebut berdasarkan pada hasil uji hipotesis yang menunjukkan bahwa total dampak big fiver personality dengan minat beli gamis pada mahasiswi yang dimoderatori oleh persepsi terhadap kualitas produk menunjukkan nilai negatif.

\section{Daftar Rujukan}

[1] Aaker, David. (1997). Manajemen ekuitas merek. Jakarta: Spektrum.

[2] Alwisol. (2012). Psikologi kepribadian. Malang: UMM Press.

[3] Assael, H. (2008). Consumer behavior and marketing action $6^{\text {th }}$ edition. New York: International Thomson Publishing.

[4] Amstrong \& Kotler, P. (2003). Manajemen Pemasaran, Edisi Kesembilan. Jakarta : PT. Indeks Gramedia

[5] Chaplin, J. P. (2014). Kamus Lengkap Psikologi. Jakarta: PT. Raja Grafindo

[6] Durianto, Darmadi, Sugiarto, dan Sitinjak, T. (2001). Strategi menaklukkan pasar melalui riset ekuitas dan perilaku merek.Jakarta: Gramedia Pustaka Utama.

[7] Feist, J., \& Gregory J. Feist. 2006. Theories of Personality Sixth Edition. United States: McGraw-Hill Companies. Inc.

[8] Feist, J., \& Feist, G.J. (2008). Theories of personality $7^{\text {th }}$ edition. New York: McGraw Hill.

[9] Gibson, James L., John M. Ivancevich, James H. Donnelly, Jr., and Robert Konopaske. (2012). Organizations: Behavior, Structure, Processes, Fourteenth Edition. New York: McGraw-Hill.

[10] John, O.P., \& Srivastava. (1999). The big five trait taxonomy: History, measurement, and theoretical perspectives. In L. A. Pervin \& O. P. John (Eds.), Handbook of personality: Theory and research. New York: Guilford Press.

[11] Kolter, P., \& Amstrong, G. (2008). Prinsip-prinsip Pemasaran. Edisi 12 Jilid 1. Jakarta: Erlangga.

[12] Kotler, P., \& Keller, K.L. (2007). Manajemen pemasaran edisi 12 jilid II. Jakarta: PT. Indeks.

[13] Kotler, P., \& Keller, K. L. (2012). Manajemen Pemasaran, Edisi 12. Jakarta : Erlangga

[14]Lucas, D. B., \& Britt, S. H. (2012). Measuring advertising effectiveness. New York: McGraw-Hill.

[15] Mowen. (1995). Perilaku Konsumen. Jakarta : Pustaka Ilmu

[16] Schiffman, L. G., \&Kanuk, L.L. (2010). Consumer behavior $7^{\text {th }}$ edition. New Jersey: Prentice-Hall.

[17] Suyono, H., Aulia \& Tamtama, F. (2015). Leadership of Indonesian Defence Forces. Laporan penelitian kerjasama kelembagaan $(P K K)$. Yogyakarta: Fakultas Psikologi Universitas Ahmad Dahlan.

[18] Tempo. (2013). 2015, Indonesia Jadi Trend Setter Fashion Muslim. https://gaya.tempo.co/read/459407/2015-indonesia-jadi-trendsetter-fashion-muslim. Diakses 5 November 2016 